\title{
CYTOLOGICAL EFFECT OF VIRUS INFECTION IN FIVE CROP SPECIES
}

\author{
Atika Naz, G. Kabir and M.M. Ud-Deen ${ }^{* 1}$ \\ Professor Sultanul Alam Cytogenetics Laboratory, Department of Botany, \\ University of Rajshahi, Rajshahi-6205, Bangladesh
}

Key words: Virus infection, Cytological effect, Plant species

\begin{abstract}
Meiotic abnormalities and pollen sterility due to virus infection in Capsicum annuum L., Carica papaya L., Lablab purpureus L., Lycopersicon esculentum L., and Solanum melongena L. were studied. Comparison in with unaffected plants showed that virus infected plants, asynapsis, multivalents and lower chiasma frequencies were present. Frequencies of chromosomal irregularities and pollen sterility were high in virus infected plants.
\end{abstract}

Different crop plant species extensively cultivated for vegetable in Bangladesh are found to be infected by viruses, resulting in the decrease of growth and development and ultimately reducing their yield. Only a few reports are available about the effect of viral diseases on the gametogenesis of plant. Kostoff (1933) studied the effect of mosaic virus infection on tobacco and reported a host of abnormalities in all the stages of meiosis. Caldwell (1952) also observed a complete breakdown of meiosis in tomato plants infected by virus. The effect of virus on Capsicum annuum studied by Swaminathan et al. (1959) showed reduced chiasma frequency, irregular anaphase separation and poor seed set. Kaul (1968) studied the effect of infection with mosaic virus on the meiotic process of Datura quarcifolia and reported complete asynapsis at diakinesis and metaphase-1 and presence of 24 univalents. Wilkinson (1953) observed nuclear abnormalities in $L$. esculentum along with pollen sterility and disruption of reproductive mechanism due to viral infection. It is known that increase in meiotic abnormalities caused an increase of pollen sterility (Reddy and Rao 1982).

In view of these reports, the present investigation was undertaken to study the cytological effects of virus infection in meiotic cells of five plant species from Bangladesh.

Both normal and virus infected Capsicum annuum L., Carica papaya L., Lablab purpureus L., Lycopersicon esculentum L. and Solanum melongena L. were used as experimental materials for the present study.

To study the chromosome association, chiasma frequency and meiotic abnormalities, young flower buds of suitable sizes from both normal and viral infected plants were collected from 9.00 a.m. to 11.00 a.m. These were fixed in $1: 3$ acetoalcohol to which a small amount of ferric acetate $(1 \mathrm{~g}$ in $500 \mathrm{ml}$ acetoalcohol) was added imparting a straw colour. After 48 hours of fixation young flower buds were rinsed with distilled water and they were preserved in $70 \%$ ethanol and kept in a refrigerator till used. Temporary slides were prepared from suitable anthers with $2 \%$ acetocarmine by using smear technique.

To study pollen sterility, the mature anthers of both normal and virus infected plants were collected at the time of anthesis. The anthers were fixed in $70 \%$ ethanol directly and kept in refrigerator till used. Temporary slides were prepared from mature anthers by using $1 \%$ acetocarmine smear technique.

${ }^{*}$ Corresponding author: E-mail: <muddeen05@yahoo.com>. ${ }^{1}$ Department of Crop Science \& Technology, University of Rajshahi, Rajshahi-6205, Bangladesh. 
Chromosome association and chiasma frequencies in normal and virus infected plants of five species were studied from their pollen mother cells (PMCs) at diakinesis. Except $L$. esculentum the normal plants of the four species were found to have almost regular bivalent formation

(Table 1). But in case of virus infected plants all the species showed irregular chromosome association. In addition to bivalent, univalent and multivalent were observed. The findings of the present study revealed that in normal plants, meiosis as well as bivalents formation were regular at diakinesis. On the other hand, in virus infected plants, asynapsis was noticed at diakinesis. The presence of univalent at diakinesis and M-I were reported by Kaul (1968). A complete break down of meiosis in plants infected with virus was reported by Kostoff (1933) in tobacco and Caldwell (1952) in tomato.

Table 1. Chromosome association and chiasma frequency in normal and virus infected five plant species.

\begin{tabular}{|c|c|c|c|c|c|c|}
\hline \multirow{3}{*}{ Plant } & \multirow{3}{*}{ Plant type } & \multirow{2}{*}{\multicolumn{3}{|c|}{$\begin{array}{c}\text { Chromosome association } \\
\text { Percentage of } \\
\end{array}$}} & \multirow{3}{*}{$\begin{array}{c}\text { Chiasmata } \\
\text { per } \\
\text { bivalent }\end{array}$} & \multirow{3}{*}{$\begin{array}{c}\text { Chiasmata } \\
\text { per } \\
\text { cell }\end{array}$} \\
\hline & & & & & & \\
\hline & & Univalent & Bivalent & Multivalent & & \\
\hline \multirow{2}{*}{ Capsicum annuum } & Normal & - & 100 & - & 1.62 & 19.38 \\
\hline & Infected & 1.66 & 98.34 & - & 1.42 & 17.14 \\
\hline \multirow{2}{*}{ Carica papaya } & Normal & - & 100 & - & 1.60 & 14.40 \\
\hline & Infected & 6.50 & 93.50 & - & 1.55 & 13.96 \\
\hline \multirow{2}{*}{ Lablab purpureus } & Normal & - & 100 & - & 1.80 & 19.90 \\
\hline & Infected & 4.27 & 95.73 & - & 1.56 & 17.20 \\
\hline \multirow{2}{*}{$\begin{array}{l}\text { Lycopersicon } \\
\text { esculentum }\end{array}$} & Normal & - & 99.83 & 0.17 & 1.53 & 18.36 \\
\hline & Infected & 5.28 & 91.25 & 3.47 & 1.36 & 16.42 \\
\hline \multirow{2}{*}{ Solamum melongena } & Normal & - & 100 & - & 1.66 & 20.00 \\
\hline & Infected & - & 97.45 & 2.55 & 1.44 & 17.28 \\
\hline
\end{tabular}

In the present study, the chiasma frequencies for both per bivalent and per cell in different plant species infected with virus were found to be lower than their respective normal plants. Swaminathan et al. (1959) reported a significant reduction in chiasma frequency and partial asynapsis in chilies infected with mosaic virus.

To study the meiotic abnormalities, stages from M-I to second T-II were observed. The different types of abnormalities such as fragments, laggards and bridges were found. Among the different types of abnormalities lagging chromosomes and chromosome bridges were found in all the species of both normal and virus infected plants. The chromosome fragments and micronuclei were not observed in any normal plants of different species except in infected $L$. esculentum species. The percentages of different meiotic abnormalities were found to vary among the normal and virus infected plants in different species. The findings also indicated that lagging chromosomes were predominate than chromosome bridges in all the species. Among the normal plants the highest and lowest chromosomal abnormalities were found in L. purpureus and $C$. annuum, respectively. But in case of virus infected plants, the highest percentage of abnormal cells (27.91) was found in S. melongena and the lowest (19.70), in C. papaya (Table 2). Cytological irregularities following virus attack on plants have been reported by some workers. Wilkinson (1953) found several cytological abnormalities in tomato infected with virus. Diaz and Pavan (1965) reported anomalies like increased cell and 
chromosome size associated with fragmentation of chromosomes. The increasing frequenscy of meiotic abnormalities in virus infected plants was reported by Kaul (1968).

Table 2 indicated that among the five infected plant species, the highest percentage of pollen sterility was found in $L$. esculentum and the lowest in $C$. papaya. The pollen sterility of virus infected plants of different plant species were higher than that of normal plants of respective species. It may be due to the incidence of higher frequency of meiotic abnormalities in infected plants. Similar results were also reported by Reddy and Rao (1982) and Peterson (1958) in C. annuum.

Table 2. Meiotic abnormalities and pollen sterility in normal and virus infected five plant species.

\begin{tabular}{|c|c|c|c|c|c|c|c|}
\hline \multirow[b]{2}{*}{ Plant } & \multirow[b]{2}{*}{ Plant type } & \multirow{2}{*}{$\begin{array}{l}\text { No. of } \\
\text { cells } \\
\text { studied }\end{array}$} & \multicolumn{2}{|c|}{ Cell division } & \multicolumn{3}{|c|}{ Pollen sterility } \\
\hline & & & $\begin{array}{l}\text { Normal } \\
\text { cells (\%) }\end{array}$ & $\begin{array}{c}\text { Abnormal cell } \\
\% \text { (laggard, } \\
\text { bridge, } \\
\text { micronuclei, } \\
\text { fragments etc.) }\end{array}$ & $\begin{array}{l}\text { No. of } \\
\text { cells } \\
\text { studied }\end{array}$ & $\begin{array}{l}\text { Fertile } \\
\text { cell (\%) }\end{array}$ & $\begin{array}{l}\text { Sterile } \\
\text { cell (\%) }\end{array}$ \\
\hline \multirow{2}{*}{ C. annuum } & Normal & 401 & 96.76 & 3.24 & 146 & 98.64 & 1.36 \\
\hline & Infected & 427 & 74.35 & 25.64 & 357 & 80.64 & 19.32 \\
\hline \multirow{2}{*}{ C. papaya } & Normal & 388 & 96.39 & 3.58 & 199 & 99.0 & 0.50 \\
\hline & Infected & 274 & 80.29 & 19.70 & 317 & 83.60 & 16.40 \\
\hline \multirow{2}{*}{ L. purpureus } & Normal & 379 & 94.20 & 5.80 & 185 & 99.68 & 0.32 \\
\hline & Infected & 361 & 78.12 & 21.88 & 209 & 79.43 & 20.57 \\
\hline \multirow{2}{*}{ L. esculentum } & Normal & 440 & 95.45 & 4.55 & 285 & 98.53 & 1.47 \\
\hline & Infected & 474 & 79.11 & 20.89 & 255 & 65.72 & 34.28 \\
\hline \multirow{2}{*}{ S. melongena } & Normal & 386 & 96.11 & 3.89 & 197 & 99.50 & 0.50 \\
\hline & Infected & 317 & 71.92 & 27.91 & 228 & 78.89 & 21.11 \\
\hline
\end{tabular}

The present investigation revealed a negative impact of virus infection on meiotic cell division of the five crop species studied.

\section{References}

Caldwell, J. 1952. Study of meiosis in virus infected tomato plants. Ann. Appl. Biol. 39: 98-102.

Diaz, M. and C. Pavan. 1965. Chromosomal anomalies due to virus infection in different crop plants. Proc. Natl. Acad. Sci. Wash. 54:1321-1327.

Kaul, B.L. 1968. A study of meiosis in virus infected Datura quarcifolia. Cytologia 33: 17-20.

Kostoff, D. 1933. Meiotic study in virus infected tobacco plants. Genetica 15: 103-114.

Peterson, P.A. 1958. Cytoplasmically inherited male sterility in Capsicum. Amer. Natur. 92: 111119.

Reddy, S.S. and G.M. Rao. 1982. Cytogenetic effects of agricultural chemicals. III. Effects of hormones "Planofix and Lihocin" on chromosomal mechanism in relation to yield and yield components in chilli (Capsicum annuum L.). Cytologia 47: 269-279.

Swaminathan, M.S., T. Ninan and M.L. Magoon. 1959. Cytological effects of mosaic virus in chillis. Genetica. 30: 63-69.

Wilkinson, J. 1953. Cytological abnormalities in tomato affected by virus. Nature. 30: 658-659. 